\title{
Parametric Analysis of the Changes a Landscape Previously Used for Transhumance in a Nature Reserve in Sicily
}

\author{
Patrizia Russo, Lara Riguccio, Laura Carullo, Giovanna Tomaselli* \\ Department of Agri-food and Environmental Systems Management, Catania University, Catania, Italy \\ Email: "gitomas@unict.it
}

Received 7 February 2014; revised 8 March 2014; accepted 21 March 2014

Copyright (C) 2014 by authors and Scientific Research Publishing Inc.

This work is licensed under the Creative Commons Attribution International License (CC BY). http://creativecommons.org/licenses/by/4.0/

(c) (i) Open Access

\begin{abstract}
Cavagrande del Cassibile is an important nature reserve in South East Sicily (Italy). It was established to conserve and restore the natural Mediterranean vegetation in the area, as well as to protect and increase the local fauna. Inside the reserve there are farms which only abandoned transhumance in the 1990s. Our research investigates whether the conversion of the farms from transhumance to fixed site stock-breeding has changed the particular landscape under investigation. The study was carried out on two scales: at territory level, in order to analyse the present potential advantages that the reserve offers to the area; and at farm level, in order to analyse the transformation of the landscape and to highlight the importance of the farms in the modern multifunctional rural context. The results at territory level show that the Cavagrande del Cassibile reserve has great potential for environmental agro-tourism. The results of the farm level analysis were obtained by elaborating certain indices (changes in the landscape, continuation of farming, farm size). These allowed the changes in the countryside to be described in quantitative terms. In general, it emerges that there have been structural changes since the days of transhumance and that this has resulted in a landscape where the effects of human activities are more visible. Lastly our research also shows the sensitivity that the stockbreeders and farmers feel for their environment and their willingness to develop activities which will encourage local tourism and excursions.
\end{abstract}

\section{Keywords}

Environmental Resources, Agricultural and Animal Husbandry Resources, Landscape Resources

${ }^{*}$ Corresponding author. 


\section{Introduction}

"Transhumance" describes a system of animal husbandry in which the livestock are moved from one farm to another, in some cases over large distances, in order to exploit the available grazing. This has been a common practice in the Mediterranean area since time immemorial, with herds and flocks being taken from the plains to the mountains in summer, in search of mountain grazing, and in winter returning to the plains, where the climate is milder. Once a particular area has been grazed out the herds or flocks move on, the vegetation can regenerate [1]-[3].

Traditional transhumance-where the animals move slowly for some days along particular routes, with established stopping places where the animals can rest and the shepherds and herdsmen sleep-was widely practised in Sicily until the 1990s. Today, although transhumance is in decline, it is still of economic importance, both in terms of providing feed for the animals and as an activity which preserves and protects natural spaces. Today what little remains of the practice involves the transfer of the herds and flocks in trucks from one area of grazing to another [4]-[6]. As a result, the old trails have fallen into disuse or are used for different purposes. The ancient trails have disappeared because they are now lost in cultivated fields or are metalled over in areas that are no longer pristine countryside, but are now densely populated. The shelters have been abandoned, and the rural houses along the migration routes are often in ruins [7]. The fields along the transhumance trails have lost the beneficial effects that the animals brought to them (grazing and natural fertilisation) [8] [9].

The way of moving the animals has changed, and many stockbreeders have also chosen to permanently keep the animals in one of the destination points of the transhumance, being it the mountains or the plains. This has meant that the way of running the farms has changed and the farmers have had to acquire new land, in order to meet the increased demand for grazing and forage. Thus abandoning transhumance has resulted in the farms becoming larger, so that they can resolve the problem of lower feed yields in the mountains in the winter and in the plains in the summer (depending on the location of the farms).

As a result, there have been changes in the farms and the landscape, both in the areas that have been used for human settlements and those that have been abandoned. Settled areas have changed because of the effects of having a constant human presence in the area, while abandoned areas have been done so because of the lack of this presence. The former have become more heavily cultivated while the latter are more likely to have returned to nature. Often these changes have occurred in areas in which the environment or the particular landscape is managed and protected by European (Natura 2000 network) or national (Parks or Reserves) norms and regulations [10].

There have also been changes at farm level. Production on farms on fixed sites is usually of the same quality as before, but is more rarely sufficiently high enough to guarantee a decent income.

Bearing in mind these considerations, this work aims to analyse the landscape changes which have occurred in the Cavagrande del Cassibile Nature Reserve after some farms which had previously practised transhumance and became fixed establishments. The intention is to highlight the qualitative and quantitative aspects of the changes and to investigate possible co-relationships between the physical changes in the landscape and the management systems used on the farms [11]-[13]. Our work may be of assistance to the regional government when they evaluate the re-qualification of the landscape and its productivity. The farms which once practised transhumance can take advantage of the intrinsic potential advantages that their past experience offers them (product quality, traditional values, culture), and thus improving not only their own situation, but also, and more importantly, contributing to the re-qualification in agricultural and tourism terms of little-appreciated places that are presently considered to be of low value. To be more precise, the farms can become a multifunctional asset, which, among other things, would encourage the farmers and farm workers to become more aware of and sensitive to environmental problems, and thus principal actors in the management of the area and the landscape [14]-[16]. The farmers, who often consider themselves as businessmen and guardians of the area, can once more become the true economic motors of the protected areas, continuing to produce unique and inimitable certificated traditional products.

\section{Materials and Methods}

The research took place in the Cavagrande del Cassibile Nature Reserve in the province of Syracusa in eastern Sicily (Figure 1). Both territorial and farm level information were taken into consideration, so that it was possible to highlight the changes to the local landscape that have occurred since transhumance was abandoned by local farmers. 


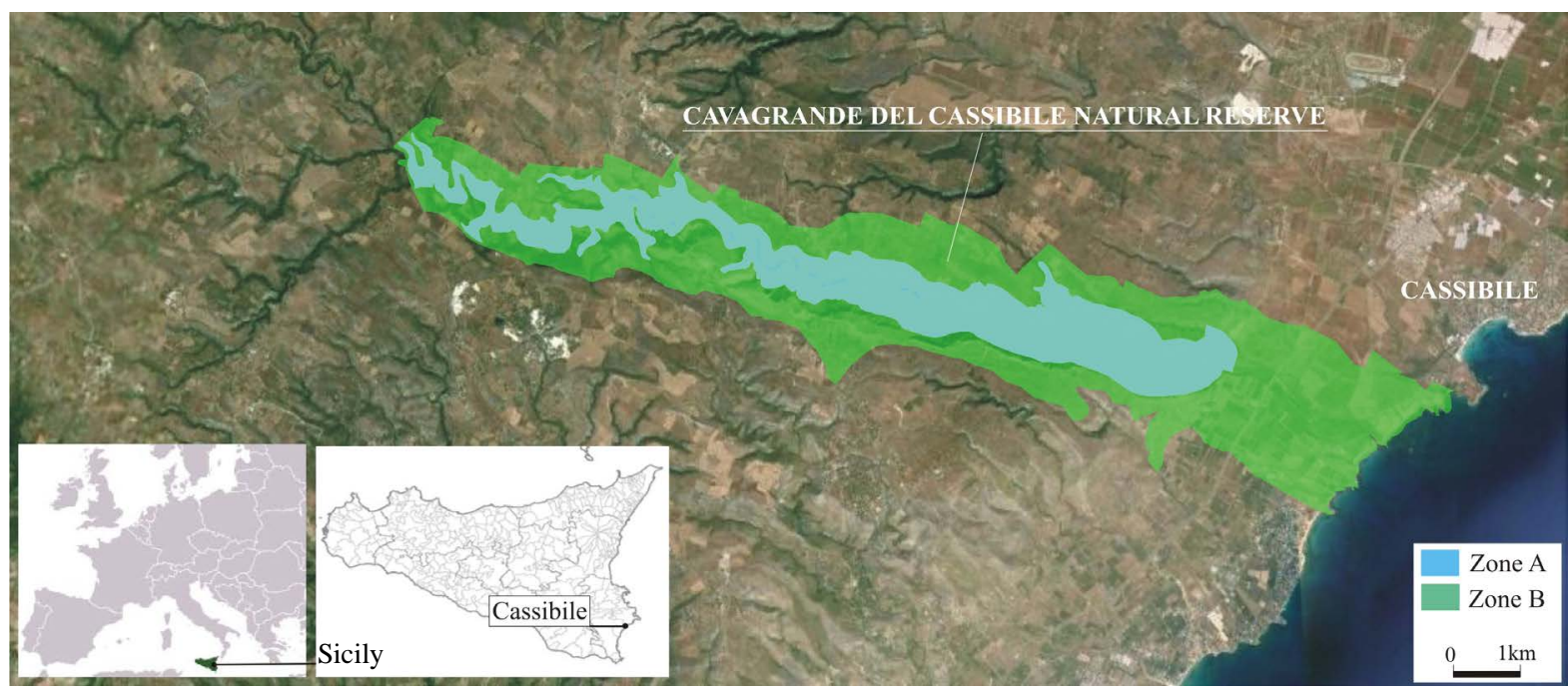

Figure 1. Plan of the area.

Analysis of the changes that have occurred was based on directly acquired data (opinion surveys completed by farmers, field analysis, interviews with farm workers) and on the basis of the cartographical information available at the GIS website of the Region of Sicily (www.bca.regionesicilia.it, www.pcn.minambiente.it), reelaborated and integrated with ArcMap from Autodesk, at a scale of 1:10,000. Historical maps from the IGM series with a scale of 1:25,000 were also used.

\subsection{Area of Research}

Cavagrande del Cassibile Nature Reserve is situated in the districts of Avola, Noto and Syracusa, in the province of Syracusa in eastern Sicily.The reserve is $27,600 \mathrm{~km}^{2}$ in area, $9000 \mathrm{~km}^{2}$ in Zone A (the reserve) and 18,600 $\mathrm{km}^{2}$ in Zone B (pre-reserve). It takes its character from the River Cassibile (the Greek Kakyparis in antiquity), which gives the area its name and which runs through the canyon that it has created over the millenia. The canyon has a maximum depth of $507 \mathrm{~m}$ and a maximum width of $1200 \mathrm{~m}$. Along the canyon bottom the river forms small pools and runs over waterfalls, creating a beautiful natural landscape. The area can be reached along a system of paths and steps. The reserve was conceived with the aim of preserving not only the value of the nature and landscape but also the archaeological and historical wealth of the area. The spontaneous vegetation found at the bottom and along the slopes of the canyon are Mediterranean maquis. There are also extremely interesting archaeological sites, which bear testimony to the presence of humans in the area since prehistoric times [17].

Although the landscape is very unspoilt, it is strongly influenced by being used for extensive agriculture, particularly animal husbandry. The land on the margins of the canyon is, indeed, used for grazing or the cultivation of cereal crops. Previously transhumance was practised, but today the animals are mainly raised on fixed sites. The animals are housed for the night in the ancient stalls that are found on the various farms. During the day the sheep and cattle graze on the land, and this helps to create its particular character [18].

\subsection{Analysis of the Landscape Used for Transhumance}

The research was carried out on two different scales:

- territorial, the whole Cavagrande Nature Reserve;

- farm level.

Research at territorial level consisted of analysing the whole area of the nature reserve in order to identify its limits and its potential ability to help the productivity of the existing farms. Today these lack the benefits that they once gained from transhumance. Transhumance fitted in with the objectives of the natural reserve, as it was established to protect the environment and give added value to the landscape [19]. Basic and thematic maps from the websites cited above were then used, in conjunction with numerous direct observations, to create new maps which show the use of the soil, the infrastructure, the pathways, the cultural and archaeological heritage and isolated buildings. 
The farm scale research investigated the six existing farms which had abandoned transhumance-they make up some $30 \%$ of the transhumance farms active in the 1990s - and which are sited completely or in part in the Cavagrande Nature Reserve. Data was collected in the field with the help of a questionnaire divided into the following sections:

- Section 1: general characteristics of the farm;

- Section 2: farm buildings;

- Section 3: breeds of animals raised;

- Section 4: multifunctional aspects of the farm.

Section 1 allowed us to gather data on the location, the extent and the use of the land and on whether or not this was inside or outside the limits of the nature reserve. The information was combined with that of 1:10,000 scale aerial maps, which showed the boundaries of the farms, the crops and the changes in cultivation that have taken place since the farms stopped practising transhumance. The historic IGM 1:25,000 scale 277-IV-NO "Noto Antica" and 277-IV-NE "Cassibile" maps were also used, as it is very possible that the land use that they show may well have continued until the 1990s. The above data was of particular importance in helping us to analyse the landscape and to elaborate the following indicators [20] [21]:

- variations in the size of the individual farms (VS);

- variations in the present size of the farms compared to when they practised transhumance (VST);

- size of farms which have not changed their type of farming (DUa);

- compaction index (CI), given from the relationship between the area and the perimeter

$$
\frac{2 \sqrt{\pi A}}{P}
$$

where $A$ is the area of the farm and $P$ its perimeter. This index has its greatest value (1) when the perimeter is circular. All other forms have lower values. The index result is 0.88 for squares and 0.83 and 0.76 for rectangles with sides with a ratio of 1:2 and 1:3, respectively. The indices were calculated for each class of land use for both the present situation and the previous historic one [20].

Sections 2 and 3 characterise the farms in terms of their buildings and productive activities. The information is used for developing hypotheses on what types of possible multifunctional development would be coherent with the infrastructure and productive activities of the particular farm.

Section 4 shows data on the management of the farms and the willingness of the farmers to combine their present activities with other multifunctional ones.

\section{Results}

\subsection{Territorial Scale}

The natural reserve takes its character from the deep canyon with the Cassibile River running through it in Zone A. The pre-reserve area is a mainly flat buffer zone along the margins of the canyon. This zone is from 0 to some 1000 metres wide.

All the vegetation in Zone A is spontaneous. It consists of Mediterranean maquis and woods. Grazing predominates in the higher areas of the pre-reserve, together with some small patches of arable land or areas used for cereal crops. Specialised farming takes place near the mouth of the Cassibile River, with the land mainly used for vegetable cultivation or fruit orchards, although there are also some irrigated areas and grazing land (Figure 2(a)).

There are provincial roads running along the edges of the nature reserve. These connect the coast with the interior. A motorway runs through the reserve near the coast, making the area easily accessible from the Cassibile intersection. The road network in the nature reserve is extensive enough for all the areas used for farming and grazing to be easily reached. It also connects the motorway with the entrances of the canyon. There are eight trails inside the canyon, leading down its steep slopes to the pools at the bottom, although not all of these are easy to use (Figure 2(b)).

The rural buildings are mainly old, and often in ruins. Of the latter, the suitable ones are used either to provide overnight housing for the animals or the shepherds and herdsmen. There are also new inhabited buildings in the pre-reserve area south of the canyon (Figure 2(b)).

Apart from the undoubted natural beauty of the nature reserve, it is also the site of important ancient cave 
dwellings, and is surrounded by historical roads and architecturally valuable rural buildings (mills and farm manor houses) (Figure 2(c)). Although the area does offer some limited services for visitors (picnic sites and car parks), the archaeological sites are not properly managed and often not even adequately indicated or described.

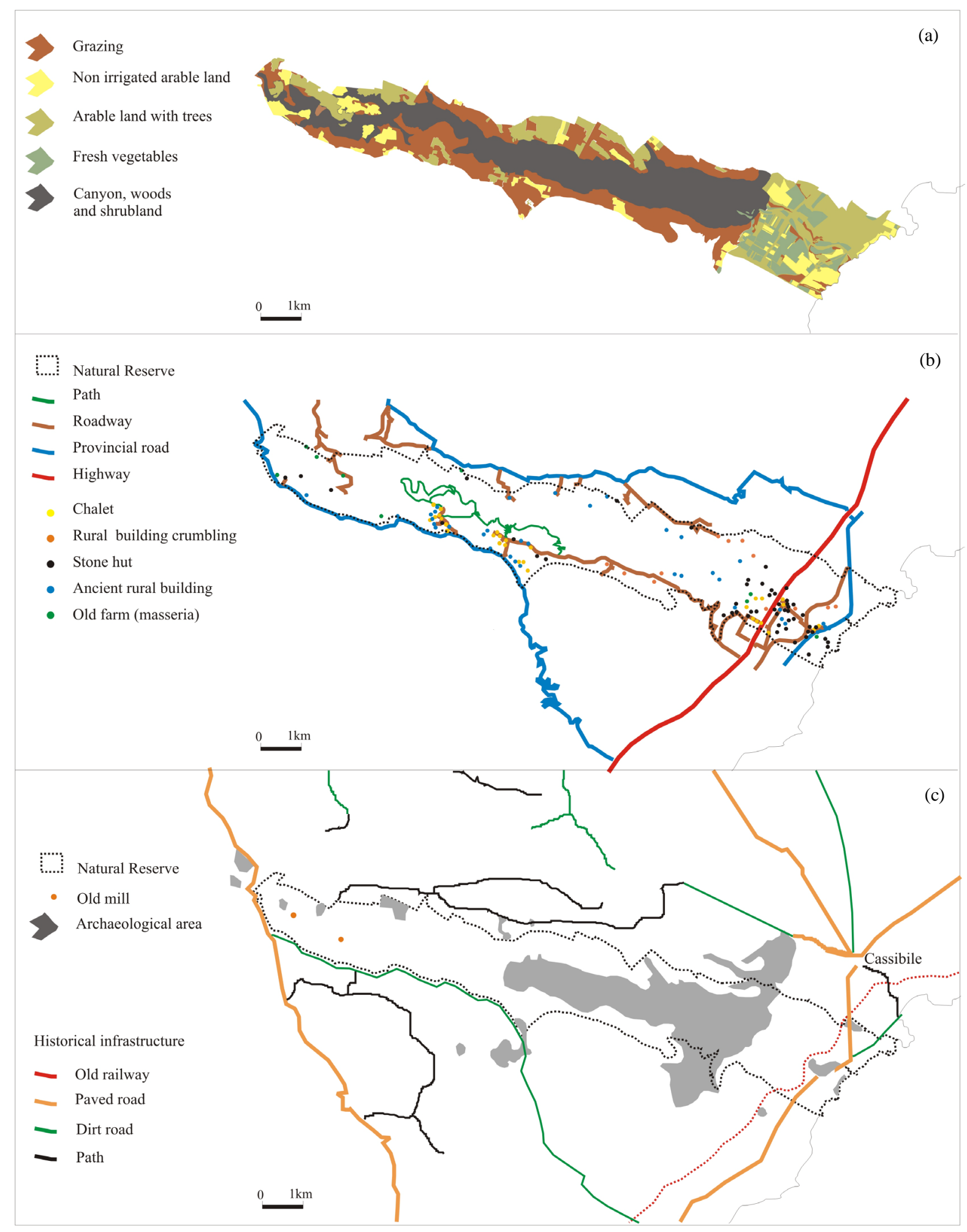

Figure 2. Main resources of the landscape: a) Land use in 2013; b) Infrastructure and buildings; c) Cultural resources. 


\subsection{Farm Scale}

Below we show the results of the elaboration of the cartographic and numeric data obtained from the questionnaires, and interpretation of the historic maps.

\subsubsection{General Characteristics of the Farms}

All of the farms in the survey are partly or totally inside the nature reserve. Most of them are rented. Most of the land is used for grazing or is arable land. In four of the farms there are woods and Mediterranean maquis. This is the typical vegetation on the walls of the canyon.

The maps of the boundaries of the present farms and those from the 1990s (when transhumance was still practised) and the changes which have occurred in these boundaries and the type of farming practised allowed us to develop certain indices which show how the landscape has been transformed since transhumance was abandoned.

The VS index (variations in the area of the farm since transhumance was abandoned) shows that the area of land occupied by the farms has increased by some $63 \%$. The index shows the average values, excluding farm 3 , which increased in size by $168.88 \%$ and farm 2 which increased by $29.97 \%$ (Table 1 , Figure 3 ).

The VST index analyses the variations in land use irrespective of where it is found on the farm. During transhumance most farm land was grazing or fallow land (51.1\%), or woods and shrubland (25.9\%). Today the former two are slightly less (50.1\%), while the latter are much less $(10.9 \%)$. This is because of a marked increase in

Table 1. Variations in the size of the farms since transhumance was abandoned (VS).

\begin{tabular}{|c|c|c|c|}
\hline & \multicolumn{2}{|c|}{ Area (ha) } & \multirow{3}{*}{$\begin{array}{c}\text { VS } \\
\text { (Increase \%) }\end{array}$} \\
\hline & \multicolumn{2}{|c|}{ Year } & \\
\hline & 1990 & 2013 & \\
\hline Farm 1 & 150.19 & 224.1 & 49.21 \\
\hline Farm 2 & 143.55 & 186.58 & 29.97 \\
\hline Farm 3 & 110.19 & 296.28 & 168.88 \\
\hline Farm 4 & 91.25 & 138.04 & 51.27 \\
\hline Farm 5 & 97.43 & 138.21 & 41.85 \\
\hline Farm 6 & 155.31 & 238.07 & 53.28 \\
\hline Total & 747.92 & 1221.28 & 63.29 \\
\hline
\end{tabular}

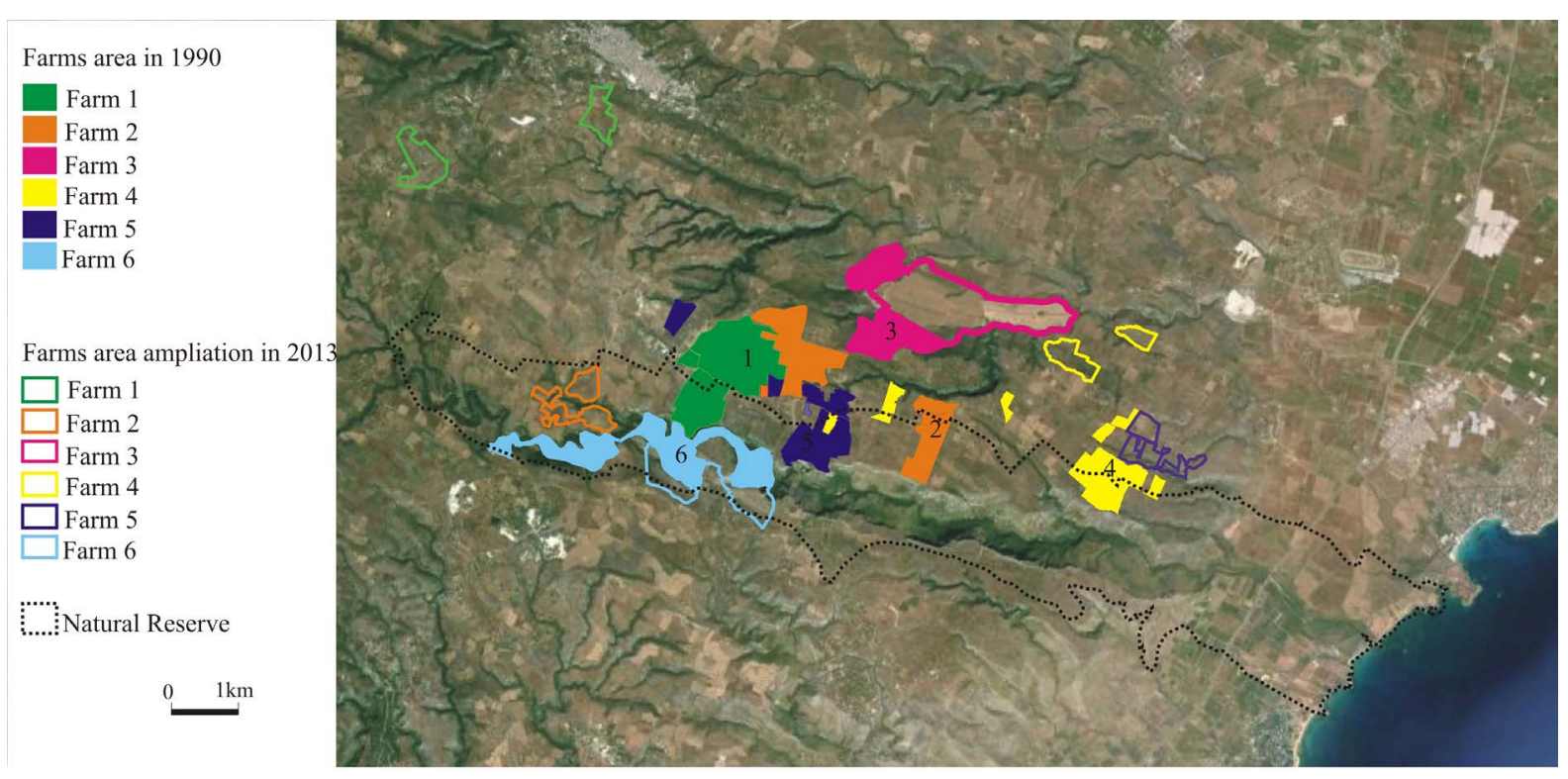

Figure 3. Farms in 1990 and in 2013. 
arable land, which has gone from $4.6 \%$ before to $27.5 \%$ today. There is a markedly lower percentage of natural land today (11.2\% compared to $17.9 \%$ when transhumance was practised). This is because the farms have become bigger. The farms have increased in size, above all increasing their amount of arable land (by $876.34 \%$ ) and grazing and fallow land (by 59.58\%), while the percentage of woods and shrubland has fallen by $31.55 \%$. There has also been a marked increase in the amount of land occupied by buildings, due to some farms having expanded in recent years (Table 2, Figure 4(a) and Figure 4(b)).

Today $66.12 \%$ of the land on the farms is still used for the same purposes as in the past, when transhumance was practised (DUa). Most is used for grazing or left fallow, and covers $73.65 \%$ of its original area. This is followed by arable land (48.49\% of the original area) and then arable land with trees (33.54\% of the original area). The natural areas are almost as large as they were during the period of transhumance (95.38\%) (Table 3, Figure $4(\mathrm{c}))$.

The lower values for the compaction indices of the farms (CI) indicate that the present boundaries of the farms are more fragmented than they were in the past. In other words the farms themselves have become more fragmented (often one farm will own parcels of land which are separated from one another) (Table 4, Figure 5).

The compaction indices for land use have lower values for each farm than they did when transhumance was practised. In general this shows how the present farms have become more fragmented. However some of the data is of notable interest.

Table 2. Soil use on the farms in 1943 and today and variations in its use.

\begin{tabular}{ccccccc} 
& $\begin{array}{c}\text { Area in } 1943 \\
\text { (ha) }\end{array}$ & $\%$ & $\begin{array}{c}\text { Area in } 2013 \\
\text { (ha) }\end{array}$ & $\%$ & $\begin{array}{c}\text { Difference } \\
\text { (ha) }\end{array}$ & $\begin{array}{c}\text { Increase \% } \\
\text { Buildings }\end{array}$ \\
Grazing & 3.75 & 0.5 & 4 & 0.3 & 0.25 & 6.67 \\
Arable land & 384.19 & 51.1 & 613.09 & 50.1 & 228.90 & 59.58 \\
Arable land with tree & 34.54 & 4.6 & 337.23 & 27.5 & 302.69 & 876.34 \\
Canyon, woods and shrubland & 194.64 & 25.9 & 133.24 & 10.9 & -61.40 & -31.55 \\
& 134.55 & 17.9 & 137.72 & 11.2 & 3.17 & 2.35 \\
\hline
\end{tabular}

Table 3. Continued use of the land.

\begin{tabular}{cccc}
\hline & $\begin{array}{c}\text { Total area in } 1943 \\
\text { (ha) }\end{array}$ & $\begin{array}{c}\text { Total area in } 2013 \\
\text { (ha) }\end{array}$ & $\begin{array}{c}\text { with same use (DUa) } \\
\%\end{array}$ \\
\hline Buildings & 3.75 & 3.75 & 100.00 \\
Grazing & 384.19 & 282.94 & 73.65 \\
Arable land & 34.54 & 16.75 & 48.49 \\
Arable land with tree & 194.64 & 65.28 & 33.54 \\
Canyon, woods and shrubland & 134.55 & 128.33 & 95.38 \\
Total & 751.67 & 497.05 & 66.12 \\
\hline
\end{tabular}

Table 4. Compaction indices (CI) in the 1990s and today.

\begin{tabular}{|c|c|c|c|c|c|c|}
\hline & $\begin{array}{c}\text { Area of the farms } \\
\text { in the } 1990 \mathrm{~s} \\
\text { (ha) }\end{array}$ & $\begin{array}{l}\text { Boundaries of the } \\
\text { farms in the } 1990 \text { s } \\
\text { (m) }\end{array}$ & $\begin{array}{l}\text { Area of the } \\
\text { farms in } 2013 \\
\text { (ha) }\end{array}$ & $\begin{array}{l}\text { Boundaries of the } \\
\text { farms in } 2013 \\
\text { (m) }\end{array}$ & $\begin{array}{c}\text { CI } \\
1990 \mathrm{~s}\end{array}$ & $\begin{array}{c}\text { CI } \\
2013\end{array}$ \\
\hline Farm 1 & 150.19 & 9547.80 & 224.1 & 15902.25 & 0.0045 & 0.0033 \\
\hline Farm 2 & 143.55 & 11816.80 & 186.58 & 17706.8 & 0.0036 & 0.0027 \\
\hline Farm 3 & 110.19 & 6707.44 & 292.4 & 11206.2 & 0.0055 & 0.0054 \\
\hline Farm 4 & 91.25 & 12533.77 & 138.04 & 17972.9 & 0.0027 & 0.0023 \\
\hline Farm 5 & 99.06 & 10527.22 & 138.21 & 17348.6 & 0.0034 & 0.0024 \\
\hline Farm 6 & 155.31 & 14445.56 & 238.07 & 14351.50 & 0.0031 & 0.0038 \\
\hline
\end{tabular}




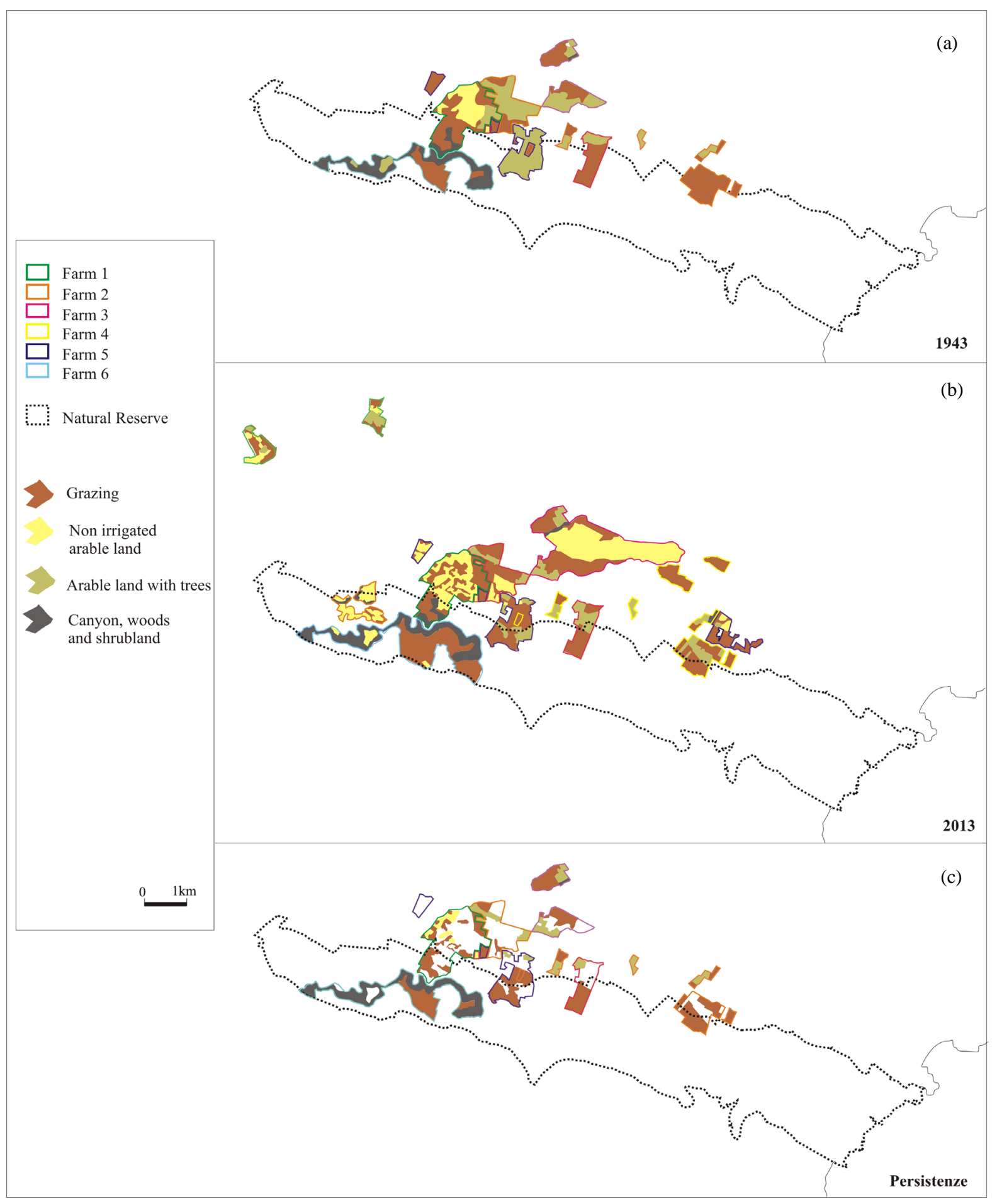

Figure 4. Land use on the farms: a) in 1943; b) in 2013; c) areas of the farms which are still used for their original purposes.

In general the values for the canyon, woods and Mediterranean maquis were the same, which is evidence of the persistence of the natural landscape, even inside the farms. The fact that some of the land was used for arable purposes on Farms 3, 5 and 6 in 2013, but not in the 1990s is due, on one hand, to extra land being used and on the other, but to a lesser extent, to land use changing from woodland to arable. This is evidence of the reduction in the woodland in the area. There is also evidence that today each class of land use is more fragmented than it 


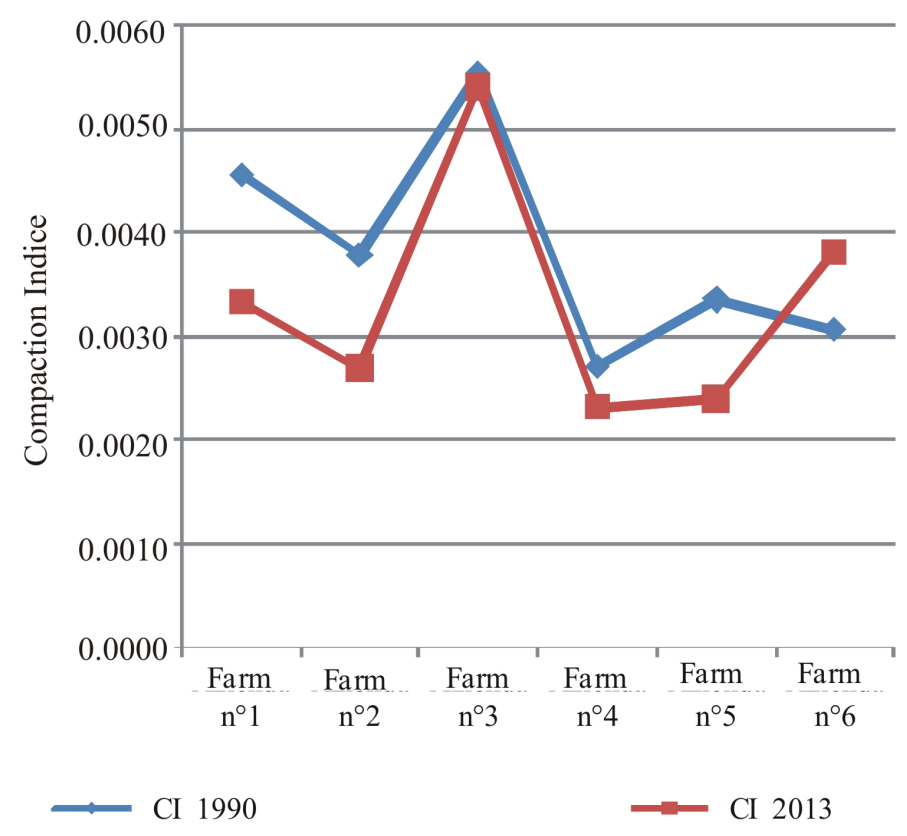

Figure 5. Compaction Indices (CI) for the farms in 1990 and 2013.

was in the past. Today parcels of arable and grazing land are interspersed among the woods in what was once completely woodland. This has created a more varied landscape, but one in which human activities are more visible than they were during the period of transhumance (Table 5).

\subsubsection{Farm Buildings}

All of the old farm buildings are still used today as temporary accommodation for the families of the farm workers and as shelter for the animals at night or in bad weather. They are still suitable for this, even though they are in good condition on only half of the farms. All the farms are supplied with water although only three are connected to the electricity network. They do not have buildings for processing the milk.

\subsubsection{Animals Raised}

Five farms raise cattle (between 50 and 100 head), and one of these also raises sheep and goats, while another two raise horses. One farm raises only sheep and goats. Farm 1 raises cattle of a mixed Sicilian-Piedmontese breed serviced by Limousin beef bulls. The farm also raises protected autochthonous Sicilian breeds in danger of extinction, and above all Ragusan donkeys. Farm 2 raises cattle of ancient Sicilian breeds, serviced by French beef bulls. Farm 3 raises autochthonous Sicilian Cinisara cows, serviced by beef bulls. Farm 4 raises mixed breed cattle, serviced by French beef bulls, as well as horses of the autochthonous San Fratellana breed. Farm 5 raises cattle of ancient Sicilian breeds crossed with French beef bulls, as well as sheep and goats of mixed breeds. Farm 6 raises autochthonous breeds of Messinese goats.

\subsubsection{Farm Multi-Functionality}

None of the farms have accommodation for visitors and they do not organise other multifunctional activities such as farm visits, B\&Bs or agro-tourism. The two farms which raise sheep and goats sell their products directly and also have the equipment for processing the products into such things as ricotta. Three farms have expressed interest in accommodating tourists and promoting the farm products. Only the farms which are interested in developing multi-functional activities attach great importance to the presence of tourists in the area and are willing to gradually start opening up the farm infrastructure to visitors. Most farmers attach medium to high importance to the establishment of the nature reserve, knowing that, apart from conserving the natural landscape, this will allow them to continue their traditional high quality farming practises, and that the presence of the nature reserve may give additional value to their products. All the farms expressed great interest in improving their infrastructures and the support services for their principal farming activities. 
Table 5. Data for calculating the compaction indices and the classes of land use.

\begin{tabular}{|c|c|c|c|c|c|c|c|c|}
\hline & $\begin{array}{l}\text { Area of land } \\
\text { use } 2013 \text { (ha) }\end{array}$ & $\begin{array}{l}\text { Boundaries of } \\
\text { land use } 2013(\mathrm{~m})\end{array}$ & $\begin{array}{l}\text { Boundaries } \\
\text { value } \%\end{array}$ & $\begin{array}{c}\text { CI } \\
2013\end{array}$ & $\begin{array}{l}\text { Area of land } \\
\text { use } 1943 \text { (ha) }\end{array}$ & $\begin{array}{c}\text { Boundaries of } \\
\text { land use } 1943(\mathrm{~m})\end{array}$ & $\begin{array}{l}\text { Boundaries } \\
\text { Value \% }\end{array}$ & $\begin{array}{c}\text { CI } \\
1943\end{array}$ \\
\hline \multicolumn{9}{|l|}{ Farm 1} \\
\hline Grazing & 102.0800 & 23661.7000 & 46 & 0.0015 & 84.0000 & 10818.7000 & 49 & 0.0030 \\
\hline Arable land & 92.3600 & 20975.6000 & 41 & 0.0016 & 32.7800 & 5426.8300 & 25 & 0.0037 \\
\hline $\begin{array}{l}\text { Arable land } \\
\text { with tree }\end{array}$ & 14.4400 & 3158.8000 & 6 & 0.0043 & 18.1900 & 2563.9000 & 12 & 0.0059 \\
\hline $\begin{array}{l}\text { Canyon, woods } \\
\text { and shrubland }\end{array}$ & 15.2200 & 3325.6000 & 7 & 0.0042 & 15.2200 & 3325.6300 & 14 & 0.0042 \\
\hline Total & - & 51121.7000 & 100 & - & - & 22135.0600 & 100 & - \\
\hline \multicolumn{9}{|l|}{ Farm 2} \\
\hline Grazing & 86.0000 & 13260.8600 & 34 & 0.00248 & 65.1100 & 6957.1000 & 48 & 0.0041 \\
\hline Arable land & 55.1800 & 13780.7400 & 36 & 0.00191 & 1.76800 & 565.0000 & 4 & 0.0083 \\
\hline $\begin{array}{l}\text { Arable land } \\
\text { with tree }\end{array}$ & 39.0000 & 7701.4000 & 20 & 0.00287 & 76.6800 & 6938.1000 & 48 & 0.0045 \\
\hline $\begin{array}{l}\text { Canyon. woods } \\
\text { and shrubland }\end{array}$ & 6.4000 & 3663.87000 & 10 & 0.00245 & - & - & - & - \\
\hline Total & - & 38406.8700 & 100 & - & - & 14460.2000 & 100 & - \\
\hline \multicolumn{9}{|l|}{ Farm 3} \\
\hline Grazing & 108.4000 & 14157.0000 & 50 & 0.0026 & 46.9800 & 5357.0000 & 45 & 0.0045 \\
\hline Arable land & 161.5000 & 8138.0000 & 29 & 0.0055 & - & - & - & - \\
\hline $\begin{array}{l}\text { Arable land } \\
\text { with tree }\end{array}$ & 22.5000 & 4223.6000 & 15 & 0.0040 & 54.8300 & 6027.8200 & 50 & 0.0044 \\
\hline $\begin{array}{l}\text { Canyon. woods } \\
\text { and shrubland }\end{array}$ & 3.8800 & 1580.4500 & 6 & 0.0044 & 8.3800 & 635.0000 & 5 & 0.0162 \\
\hline Total & - & 28099.0500 & 100 & - & - & 12019.8200 & 100 & - \\
\hline \multicolumn{9}{|l|}{ Farm 4} \\
\hline Grazing & 103.2300 & 15481.9000 & 66 & 0.0023 & 73.8200 & 8780.6000 & 68 & 0.0035 \\
\hline \multicolumn{9}{|l|}{ Arable land } \\
\hline $\begin{array}{l}\text { Arable land } \\
\text { with tree }\end{array}$ & 34.8100 & 8039.6700 & 34 & 0.0026 & 17.4300 & 4221.3000 & 32 & 0.0035 \\
\hline $\begin{array}{l}\text { Canyon. woods } \\
\text { and shrubland }\end{array}$ & - & - & - & - & - & - & - & - \\
\hline Total & - & 23521.5700 & 100 & - & - & 13001.9000 & 100 & - \\
\hline \multicolumn{9}{|l|}{ Farm 5} \\
\hline Grazing & 98.0000 & 18532.6300 & 64 & 0.0019 & 78.1000 & 8193.8500 & 76 & 0.0038 \\
\hline Arable land & 17.7200 & 4875.9800 & 17 & 0.0031 & - & - & - & - \\
\hline $\begin{array}{l}\text { Arable land } \\
\text { with tree }\end{array}$ & 22.4900 & 5572.8600 & 19 & 0.0030 & 19.3300 & 2544.8500 & 24 & 0.0061 \\
\hline $\begin{array}{l}\text { Canyon. woods } \\
\text { and shrubland }\end{array}$ & - & - & - & - & - & - & - & - \\
\hline Total & - & 28981.4700 & 100 & - & - & 10738.7000 & 100 & - \\
\hline \multicolumn{9}{|l|}{ Farm 6} \\
\hline Grazing & 115.3800 & 9442.0400 & 34 & 0.0040 & 36.1800 & 3908.4500 & 18 & 0.0055 \\
\hline Arable land & 10.4700 & 2690.7400 & 9 & 0.0043 & - & - & - & - \\
\hline $\begin{array}{l}\text { Arable land } \\
\text { with tree }\end{array}$ & - & - & - & - & 8.1800 & 1710.4000 & 8 & 0.0059 \\
\hline $\begin{array}{l}\text { Canyon. woods } \\
\text { and shrubland }\end{array}$ & 112.2200 & 15978.1800 & 57 & 0.0023 & 110.9500 & 15850.8700 & 74 & 0.0024 \\
\hline Total & - & 28110.9600 & 100 & - & - & 21469.7200 & 100 & - \\
\hline
\end{tabular}


To be more precise, all the farms attached most importance to improving the road network inside the nature reserve. When asked "Which services are indispensable for encouraging the activities of the farm?" almost all the farms mentioned the establishment of local markets, while a minority mentioned the establishment of cooperatives and improving the infrastructure.

\section{Discussion of the Results and Conclusions}

The abandonment of traditional transhumance has not only led to clear and apparent cultural losses, but has also, without question, transformed the landscape.

The territorial scale analysis of the whole area of the nature reserve showed the various possibilities that the presence of the long-established working farms in the reserve could offer for the future. Farming along the coast is intensive, while the farms on the inland plateau practice fixed animal husbandry, with the land being used for grazing and arable farming. These farms could supply local markets, as all the farmers wish to do. The area has an adequate road network and there is a good network of paths in Zone A. The buildings, especially the ancient farm buildings and the old rural dwellings, could also provide excellent support to local tourism [15] [22] [23].

Farm Level Analysis highlighted certain aspects which are of marked interest, both in terms of understanding the changes that have taken place in the landscape in the last thirty years after transhumance was abandoned and in terms of the organisational assets of the farms in the sample. To be more precise, these are:

- abandonment of transhumance has led to a clear and apparent change in the use of the land, with more arable farming and a more marked and visible human impact on the landscape;

- the increase in the size of the farms has had an effect on the landscape, because the farmers are using the new land for forage crops, which increases the visible human impact;

- the changes in both the overall size of the farms and the amount of land that is dedicated to particular uses influence the Compaction Indices (CI). Analysis of these showed that the farms are more fragmented, and this has also increased the visible human impact on the landscape since the days of transhumance;

- the indices which we analysed (VST, DUa and CI) show that the land covered by woods or in the canyon occupies the same amount of land as it did before;

- continued use of the land for the same purposes as before is most common in areas which are difficult to cultivate, such as grazing, fallow land, woods and the canyon;

- the farmers are aware of the touristic and environmental potential of their land and expressed their willingness to integrate their main activities with collateral activities that would encourage and assist tourism in the nature reserve.

Thus the results of our research show on one hand that there is now more human impact on the landscape today than there was in the days of transhumance and on the other hand show the willingness of the farmers to engage and support innovative actions which will protect and give added value to the area and the landscape [24]. The farmers know that this is the best way for them to continue and develop their activities. The recent past of the farms provides a solid cultural base for encouraging the development of multifunctional farming, animal husbandry and ecological activities [25].

Even though the research investigates a specific territorial environment, it is also of more general interest, for the following reasons:

- The method may be used in similar contexts and may produce interesting results for other areas where it is used;

- Demonstrating the effects of the abandonment of transhumance on the landscape in the area studied supplies useful information which can be used to help protected areas from becoming too anthropomorphised. This is because even today transhumance still guarantees the historic stability of the landscape.

\section{Acknowledgements}

The authors would like to thank Dr. Davide Calà Lesina for his invaluable collaboration in all stages of the research and for having elaborated the data and created the maps in this study.

\section{References}

[1] Olea, P.P. and Mateo-Tomás, P. (2009) The Role of Traditional Farming Practices in Ecosystem Conservation: The Case of Transhumance and Vultures. Biological Conservation, 1, 1844-1853.

http://dx.doi.org/10.1016/j.biocon.2009.03.024 
[2] O’Flanagan, P., Lasanta Martínez, T. and Paz Errea Abad, M. (2011) Restoration of Sheep Transhumance in the Ebro Valley, Aragon, Spain. The Geographical Review, 4, 556-575. http://dx.doi.org/10.1111/j.1931-0846.2011.00117.x

[3] Ladio, A.H. and Lozada, M. (2004) Summer Cattle Transhumance and Wild Edible Plant Gathering in a Mapuche Community of Northwestern Patagonia. Human Ecology, 2, 225-240. http://dx.doi.org/10.1023/B:HUEC.0000019764.62185.99

[4] Ladio, A.H. and Lozada, M. (2009) Human Ecology, Ethnobotany and Traditional Practices in Rural Populations Inhabiting the Monte Region: Resilience and Ecological Knowledge. Journal of Arid Environments, 73, 222-227. http://dx.doi.org/10.1016/j.jaridenv.2008.02.006

[5] Azcarate, F.M., Robleno, I., Seoane, J., Manzano, P. and Peco, B. (2013) Drove Roads as Local Biodiversity Reservoirs: Effects on Landscape Pattern and Plant Communities in a Mediterranean Region. Applied Vegetation Science, 16, 480-490. http://dx.doi.org/10.1111/avsc.12003

[6] Cassaniti, S. (2002) Disponibilità di risorse foraggere e movimenti zonali degli animali in allevamento nell'area dei Monti Nebrodi. Proceedings of Accademia dei Georgofili, Firenze, XLVIII, 573-608.

[7] Dal Sasso, P. and Caliandro, L.P. (2010) The Role of Historical Agro-Industrial Buildings in the Study of Rural Territory. Landscape and Urban Planning, 3, 146-162. http://dx.doi.org/10.1016/j.landurbplan.2010.03.003

[8] Hevia, V., Azcarate, F.M., Oteros-Rozas, E. and Gonzalez, J.A. (2013) Exploring the Role of Transhumance Drove Roads on the Conservation of ant Diversity in Mediterranean Agroecosystems. Biodivers Conserv, 22, 2567-2581. http://dx.doi.org/10.1007/s10531-013-0539-8

[9] Grellier, B. (2006) A Transhumant Shepherd on Mount Aigoual: Sheep Transhumance and the Shepherd’s Knowledge. Blackwell Publishing Ltd., Oxford, 162-164.

[10] Russo, P., Carullo, L., Riguccio, L. and Tomaselli, G. (2011) Identification of Landscapes for Drafting Natura 2000 Network Management Plans: A Case Study in Sicily. Landscape and Urban Planning, 3, 228-243. http://dx.doi.org/10.1016/j.landurbplan.2011.02.028

[11] Antrop, M. (1997) The Concept of Traditional Landscapes as a Base for Landscape Evolution Planning, the Example of Flanders Region. Landscape Urban Planning, 38, 105-117. http://dx.doi.org/10.1016/S0169-2046(97)00027-3

[12] Antrop, M. (2000) Background Concepts for Integrated Landscape Analysis. Agriculture, Ecosystems \& Environment, 77, 17-78. http://dx.doi.org/10.1016/S0167-8809(99)00089-4

[13] Antrop, M. (2005) Why Landscapes of the Past Are Important for the Future? Landscape Urban Planning, 70, 21-34 http://dx.doi.org/10.1016/j.landurbplan.2003.10.002

[14] Bonfanti, P., Fregonese, A. and Sigura, M. (1997) Landscape Analysis in Areas Affected by Land Consolidation. Landscape Urban Planning, 37, 91-98. http://dx.doi.org/10.1016/S0169-2046(96)00373-8

[15] Russo, P., Riguccio, L., Carullo, L. and Tomaselli, G. (2013) Using the Analytic Hierarchical Process to Define Choices for Re-Using Rural Buildings: Application to an Abandoned Village in Sicily. Natural Resources, 4, 323-332. http://dx.doi.org/10.4236/nr.2013.44039

[16] Aizaki, H., Sato, K. and Osari, H. (2006) Contingent Valuation Approach in Measuring the Multifunctionality of Agriculture and Rural Areas in Japan. Paddy and Water Environment, 4, 217-222. http://dx.doi.org/10.1007/s10333-006-0052-8

[17] (1999) Landscape Plan of Sicily. http://bca.regione.sicilia.it/ptpr/main/index.htm

[18] Atripaldi, A.M. and Calvagna, S. (2010) Le forme del paesaggio “Dall’Etna agli Iblei”. ANABIBLO Edizioni, Roma.

[19] Fichera, C.R. (2007) Multifunzionalità e sviluppo sostenibile del territorio rurale. Innovazione tecnologica e valorizzazione delle tipicità in aree marginali. Iiriti editore, Reggio Calabria.

[20] Ludwiczak, Z., Benni, S. and Tassinari, P. (2013) The Study of Rural Landscape at the Farm Scale: Changes in Traditional Signs and Structures. Journal of Agricultural Engineering, e88, 436-440.

[21] Farina, A. (2001) Ecologia del paesaggio. UTET, Torino.

[22] Riguccio, L., Russo, P., Scandurra, G. and Tomaselli, G. (2013) Cultural Landscape: Stone Towers on Mount Etna. Landscape Research, Published online. http://dx.doi.org/10.1080/01426397.2013.829809

[23] Torreggiani, D. and Tassinari, P. (2012) Landscape Quality of Farm Buildings: The Evolution of the Design Approach in Italy. Journal of Cultural Heritage, 13, 59-68. http://dx.doi.org/10.1016/j.landurbplan.2014.01.005

[24] De Montis, A. (2014) Impacts of the European Landscape Convention on National Planning Systems: A Comparative Investigation of Six Case Studies. Landscape and Urban Planning, 124, 53-65. http://dx.doi.org/10.1016/j.foreco.2007.04.042

[25] Holl, K. and Smith, M. (2007) Scottish Upland Forests: History Lessons for the Future. Forest Ecology and Management, 249, 45-53. http://dx.doi.org/10.1016/j.foreco.2007.04.042 